\title{
Input Current Quality Parameters Analysis of Modular AC-DC SEPIC Charger Based on Double Fourier Series
}

\author{
Ie. V. Verbytskyi, PhD Assoc.Prof., ORCID 0000-0001-7275-5152 \\ Department of Electronic Devices and Systems eds.kpi.ua \\ National Technical University of Ukraine "Igor Sikorsky Kyiv Polytechnic Institute" kpi.ua \\ Kyiv, Ukraine
}

\begin{abstract}
Review of AC chargers topologies with active power factor correction are considered in the paper. Single and double-stage charger topologies are highlighted and the feasibility of using the first group of converters is substantiated because of its smaller size and simpler structure. Among single-stage converters, the advantages of modular converters based on SEPIC topologies are emphasized because of minimal dynamic losses, a simple algorithm, and circuit implementation of power factor correction at the boundary condition mode (BCM) of input current and small dimensions. The operation of modular converters is analyzed on the example of a two-cell converter and the principle of improving the shape of the input current under the condition of shifting control pulses of each cell is shown. As a result, the functional dependence of the electricity quality parameters (power factor PF and the total harmonic distortion THD) on the pulse ratio of each converter cell is established. Since it is difficult to comply BCM in real converters, and in continuous mode the shape of the input current is distorted, such converters operate in the discontinuous conduction mode (DCM) of input current. Based on the analysis of equivalent circuits in three intervals of operation of the SEPIC converter - interval of increase of input current, interval of decrease of input current and interval of zero pause - its mathematical model was created. It is shown that the increase of relative zero current interval duration significantly worsens the value of the power factor PF and the total harmonic distortion THD. As a result, the PF and THD parameters are functions of duty cycle and the relative zero current interval duration and have a complex relationship. Therefore, in order to estimate the number of converter cells that provide the required PF and THD values, it is advisable to derive these dependencies in analytical form, based on the use of a Double Fourier series. The obtained dependencies simplify the selection of the number of cells of the converter for a given range of duty cycle and the relative zero current interval duration. PF and THD dependencies for two, three and four cells are constructed on the basis of the derived formulas.
\end{abstract}

Keywords - modular converter; SEPIC converter; charger; power factor correction; Double Fourier series

\section{INTRODUCTION}

Batteries of electric vehicles usually charged from AC grid with two-stage ac-dc converters [1]. The first stage is power factor pre-regulator (PFP), another one is an isolated $\mathrm{dc}-\mathrm{dc}$ converter. Nowadays for power applications a variety of one-stage chargers with improved efficiency are proposed [2-4]. Interleaved SEPIC converters operating in discontinuous conduction mode (DCM) have a number of advantages as chargers with built in power factor $(\mathrm{PF})$ correction [5-8]:

- it operates as a voltage follower, meaning that the input current naturally follows the input voltage;

- a current control loop can be omitted;

- galvanic isolation can be easily implemented and several isolated outputs provided;

- the input current ripple continuous and defined during the design stage;

- can operate as step-up or step-down converter
- ZCS of the transistor and ZVS of the output diode is provided.

According to such advantages interleaved SEPIC topology were used as a charger for power-assist wheelchair [9]. A topology and simple analyze of the charger's operation modes are given in [10]. For clear chosen of the charger cell number it is necessary to research dependency input current PF and THD depend on cell number $N$ and the converter duty cycle range $\gamma$.

An analysis of PF and THD based Fourier variable is inefficient because of necessity to recalculate current spectrum after each current parameter changing therefore it is proposed to use a Double Fourier series [11] that allows obtain PF and THD values for different $N$ and $\gamma$.

\section{MODEL OF THE INTERLEAVED SEPIC CONVERTER INPUT CURRENT}

Let assume an abstract two cell converter with an ideal shape input current in border current mode (BCM) that provide maximum PF, shown in Fig. 1. The input current $i_{\text {in }}$ is a total current of two cells $i_{\text {cell } 1}$ and $i_{\text {cell } 2}$ shifted on half period $T / 2$. The advantage of BCM that sine of 
input current is provided with constant pulse width $\gamma T$ [12]. Let analyze the input current shape of SEPIC converter, Fig. 2. For the analysis, it is assumed that:

- capacitors $C_{i}$ and $C_{o}$ are large enough to neglect the voltage ripple across them;

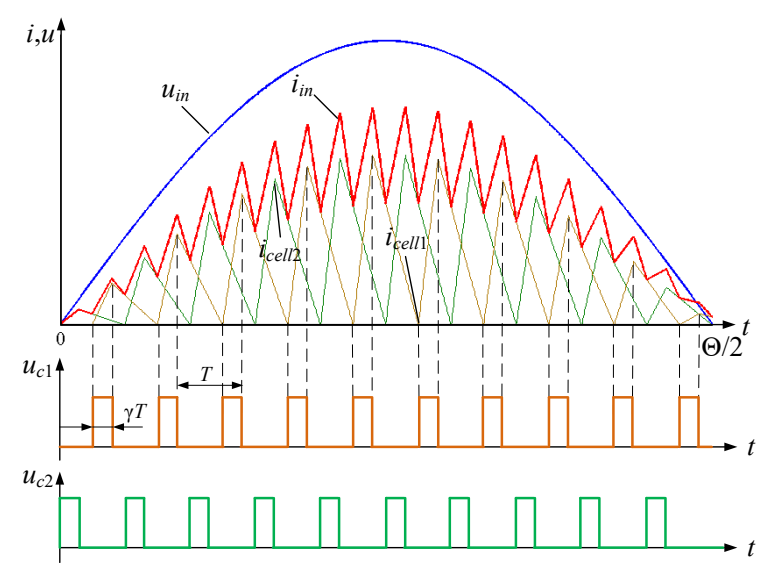

Fig. 1. Current of two-cell ideal converter in DCM

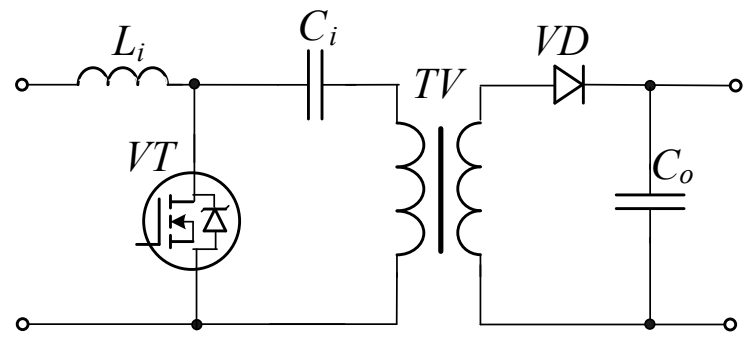

Fig. 2. SEPIC converter scheme

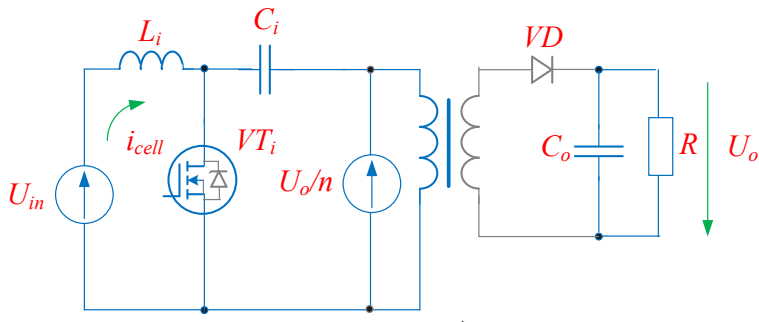

a)
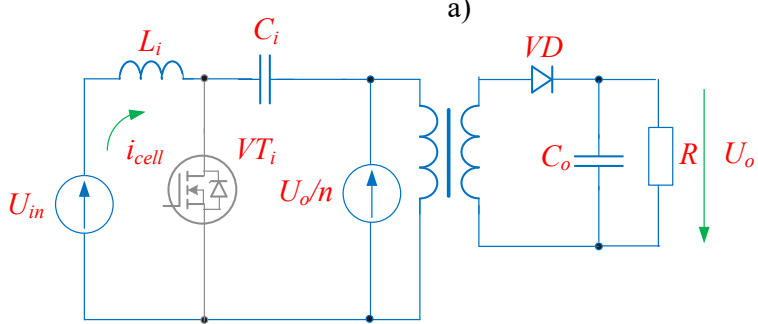

b)

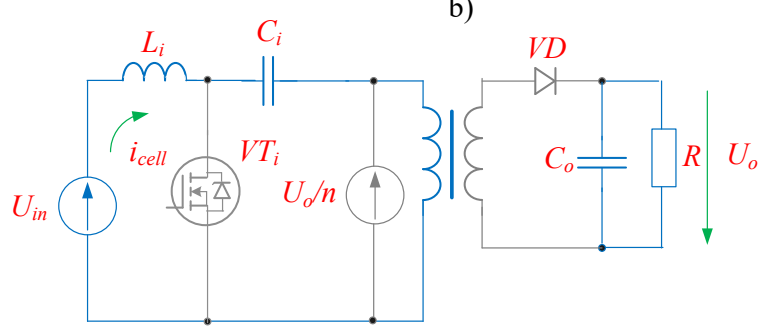

c)
- PWM period $T$ significantly less than input voltage period $\Theta, T<<\Theta$, therefore input voltage $u_{\text {in }}$ during PWM period $k, T_{k}$ has approximately constant value $u_{\text {in }(k)}=U_{\text {in }}=$ const;

- all SEPIC elements are ideal.

The DCM SEPIC has three equivalent circuits as shown in Fig. 3.

When transistor $V T_{i}$ is switched on the cell input current $i_{\text {cell }}$ rises from zero value to maximum value $I_{\text {cell } \max }$ as follows:

$$
i_{\text {cell }}(t)=\frac{U_{\text {in }}}{L_{i}} t, 0<t \leq \gamma T .
$$

where $L_{i}$ is input inductance of the cell, $U_{i n}$ is input voltage value.

On the second interval the cell input current declines to zero:

$$
i_{c e l l}(t)=I_{c e l l \_\max }-\frac{U_{o}}{n L_{i}}(t-\gamma T), \gamma T<t \leq T-t_{0},
$$

where $u_{C i}$ is voltage on capacitor $C_{i}, U_{o}$ is output voltage, $u_{C i}=U_{i n}, t_{0}$ is duration of third interval.

On third interval the cell input current is neglected, $i_{\text {cell }}=0$. Third interval $i_{\text {cell }}=0$ worsens input current shape, so it should be minimized. However, continuous current mode also unfavorable for PF correction because significant current distortion [10]. So, PF and THD of input current should be analyzed.

\section{INPUT CURRENT ANALYSIS BASED ON A DOUBLE FOURIER SERIES}

A Double Fourier series [10,11] allows to separate impact of a modulated function and a carrier function into spectrum of a pulse modulated signal due to their independent representation. The carrier function angle variable $x_{1}=\omega_{1} \cdot t$, and the modulated function angle variable $x_{2}=\omega_{2} \cdot t$ may have any relation, where $\omega$ and $\Omega$ are angular frequencies of the carrier and modulated functions, $t$ is time variable. Thus a modulation multiplicity parameter $P=x_{1} / x_{2}$ may have any positive value (integer or fractional). Therefore, Double Fourier Series provides a simple analytical model that allows:

- define PF and THD for any modulation multiplicity parameter $P$ in analytical form;

- detect interharmonics caused the fractional value of parameter $P$;

- minimize calculations.

Coefficients $C_{(m 1)(m 2)}$ of the Double Fourier Series are the spectral components of the signal with multiplicity $m_{1}$ relatively to the carrier frequency and the multiplicity $m_{2}$ relatively to the modulation frequency:

$$
\begin{aligned}
& C_{\left(m_{1}\right)\left(m_{2}\right)}= \\
& =\frac{1}{2 \pi^{2}} \int_{0}^{2 \pi} \int_{\varphi_{1}}^{\varphi_{2}} f\left(x_{1}, x_{2}\right) e^{j\left(m_{1} x_{1}+m_{2} x_{2}\right)} d x_{1} d x_{2},
\end{aligned}
$$

Fig. 3. DCM SEPIC has three equivalent circuits 
where $f\left(x_{1}, x_{2}\right)$ is a function of two variables $x_{1}$ and $x_{2}$ whose spectrum is calculated, $\varphi_{1}$ and $\varphi_{2}$ are integration limits that define pulses position relatively variable $x_{1}$.

The Double Fourier Series applying express's the spectral characteristics of the modulated signal in an analytical closed form for any multiplicity parameter $P$. The signal harmonic with number $k, C_{k}$ is calculated as follows [13]:

$$
C_{k}=\sum_{m_{1}=0}^{\infty} C_{m_{1}\left(k-m_{1} P\right)}
$$

The cell ideal input current spectrum is defined as current sum on first interval $x_{1} \in[0,2 \pi \cdot \gamma)$ where the cell current growths and second interval $x_{1} \in[2 \pi \cdot \gamma, 2 \pi)$ where the current falls down to zero.

On the first interval, for defined angle $x_{2}$ of modulated function the cell input current starts from zero value, $i_{\text {cell }}(0)=0$, and achieves value $I_{\text {cell } \max }=A \sin \left(x_{2}\right)$, where angle $x_{2}$ of modulation function corresponds angle $2 \pi \cdot \gamma$ of the carrier function. Constant $A$ is the current amplitude for $x_{2}=\pi / 2$, formula (1):

$$
A=\frac{U_{\text {in_max }}}{L_{i}} \gamma T \text {. }
$$

where $U_{\text {in_max }}$ is amplitude value of the input sinusoidal voltage.

On the end of second interval the cell ideal current starts from $I_{\text {cell_max }}$ and at $x_{1}=2 \pi$ it always tends to zero, $i_{\text {cell }}(2 \pi)=0$. Therefore, the cell input current on $i$ interval of carrier period $i$ defined as follows:

$$
i_{\text {cell }}\left(x_{1}\right)=\left\{\begin{array}{l}
\frac{A \sin \left(x_{2}\right) x_{1}}{2 \pi \gamma}, 0 \leq x_{1}<2 \pi \gamma ; \\
\frac{A \sin \left(x_{2}\right)\left(2 \pi-x_{1}\right)}{2 \pi(1-\gamma)}, 2 \pi \gamma \leq x_{1}<2 \pi .
\end{array}\right.
$$

According to formula (3) the Double Fourier Series spectrum components $C_{(m 1)(m 2)}$ calculated as follows:

$$
\begin{gathered}
C_{\left(m_{1}\right)\left(m_{2}\right)}=\frac{A}{2 \pi^{2}} \int_{0}^{\pi} \sin \left(x_{2}\right)\left(\begin{array}{l}
\frac{1}{2 \pi \gamma} \int_{0}^{2 \pi \gamma} x_{1} e^{j\left(m_{1} x_{1}+m_{2} x_{2}\right)} d x_{1}- \\
-\frac{1}{2 \pi(1-\gamma)} \int_{2 \pi \gamma}^{2 \pi} x_{1} e^{j\left(m_{1} x_{1}+m_{2} x_{2}\right)} d x_{1}+\frac{1}{(1-\gamma)} \int_{2 \pi \gamma}^{2 \pi} e^{j\left(m_{1} x_{1}+m_{2} x_{2}\right)} d x_{1}
\end{array}\right) d x_{2}+ \\
+\frac{A}{2 \pi^{2}} \int_{\pi}^{2 \pi} \sin \left(x_{2}\right)\left(\begin{array}{l}
\frac{1}{2 \pi \gamma} \int_{0}^{2 \pi \gamma} x_{1} e^{j\left(m_{1} x_{1}+m_{2} x_{2}\right)} d x_{1}- \\
-\frac{1}{2 \pi(1-\gamma)} \int_{2 \pi \gamma}^{2 \pi} x e^{j\left(m_{1} x_{1}+m_{2} x_{2}\right)} d x_{1}+\frac{1}{(1-\gamma)} \int_{2 \pi \gamma}^{2 \pi} e^{j\left(m_{1} x_{1}+m_{2} x_{2}\right)} d x_{1}
\end{array}\right) d x_{2} .
\end{gathered}
$$

In the second clause we will change the limits of integration to $[0, \pi)$.

$$
C_{\left(m_{1}\right)\left(m_{2}\right)}=\frac{A}{2 \pi^{2}}\left(1-(-1)^{m_{2}}\right) \int_{0}^{\pi} \sin \left(x_{2}\right) e^{j m_{2} x_{2}} \times\left(\frac{1}{2 \pi \gamma} \int_{0}^{2 \pi \gamma} x_{1} e^{j m_{1} x} d x_{1}-\frac{1}{2 \pi(1-\gamma)} \int_{2 \pi \gamma}^{2 \pi}\left(x_{1}-2 \pi\right) e^{j m_{1} x_{1}} d x_{1}\right) d x_{2} .
$$

From the formula (8) we can conclude that the integral is zero for even $m_{2}$, and for odd $m_{2}$ it is simplified to:

$$
C_{\left(m_{1}\right)\left(2 m_{2}-1\right)}=\frac{A}{\pi^{2}} \int_{0}^{\pi} \sin \left(x_{2}\right) e^{j\left(2 m_{2}-1\right) x_{2}} \times\left(\frac{1}{2 \pi \gamma} \int_{0}^{2 \pi \gamma} x_{1} e^{j m_{1} x_{1}} d x_{1}-\frac{1}{2 \pi(1-\gamma)} \int_{2 \pi \gamma}^{2 \pi}\left(x_{1}-2 \pi\right) e^{j m_{1} x_{1}} d x_{1}\right) d x_{2} .
$$

Spectral coefficient (9) has only two types of nonzero values:

$$
\begin{gathered}
C_{\left(m_{1}\right)(1)}=j \frac{A\left(1-e^{2 j \gamma m_{1} \pi}\right)}{4 \pi^{2}(\gamma-1) \gamma m_{1}^{2}} ; \\
C_{\left(m_{1}\right)(-1)}=-j \frac{A\left(1-e^{2 j \gamma m_{1} \pi}\right)}{4 \pi^{2}(\gamma-1) \gamma m_{1}^{2}} ; C_{(0)(1)}=\frac{j A}{2} .
\end{gathered}
$$

According to formulas (4) and (10) nonzero harmonic are calculated as follows:

$$
\begin{gathered}
C_{1}=j \frac{A}{2} ; \\
C_{2 k-1}=0,2 k-1 \neq m_{1} P+1,2 k-1 \neq m_{1} P-1 ; \\
C_{m_{1} P+1}=j \frac{A\left(1-e^{2 j \gamma m_{1} \pi}\right)}{4 \pi^{2}(\gamma-1) \gamma m_{1}^{2}} ; \\
C_{m_{1} P-1}=-j \frac{A\left(1-e^{2 j \gamma m_{1} \pi}\right)}{4 \pi^{2}(\gamma-1) \gamma m_{1}^{2}} .
\end{gathered}
$$

For a converter with $N$ cells the total spectral coefficients are defined as follow: 


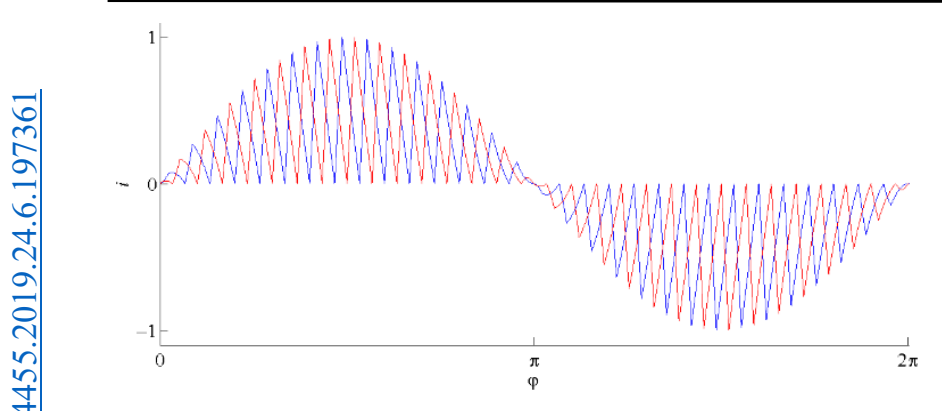

Fig. 4. Two cell current in BCM

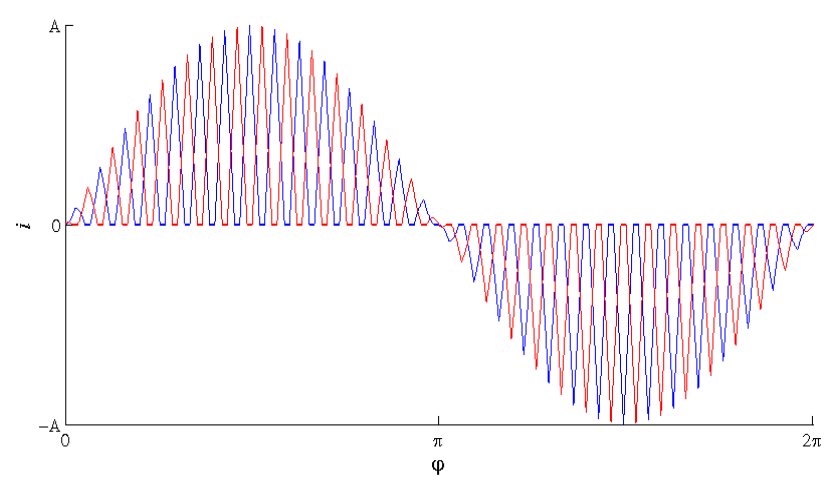

Fig. 5. Two cell current in DCM

$$
\begin{gathered}
C_{\left(m_{1}\right)(1) \Sigma}=j \frac{A\left(1-e^{2 j \gamma m_{1} \pi}\right)}{4 \pi^{2}(\gamma-1) \gamma m_{1}^{2}} \sum_{l=0}^{N-1} e^{\frac{j l 2 \pi}{N}} ; \\
C_{\left(m_{1}\right)(-1) \Sigma}=-j \frac{A\left(1-e^{2 j \gamma m_{1} \pi}\right)}{4 \pi^{2}(\gamma-1) \gamma m_{1}^{2}} \sum_{l=0}^{N-1} e^{\frac{j l 2 \pi}{N}} ; \\
C_{(0)(1)}=\frac{j N A}{2} .
\end{gathered}
$$

Thus, only spectral coefficients with number $m_{1} N$ have nonzero value:

$$
\begin{gathered}
C_{\left(m_{1} N\right)(1) \Sigma}=j \frac{A\left(1-e^{2 j \gamma m_{1} \pi}\right) N}{4 \pi^{2}(\gamma-1) \gamma\left(m_{1} N\right)^{2}} ; \\
C_{\left(m_{1} N\right)(-1) \Sigma}=-j \frac{A\left(1-e^{2 j \gamma m_{1} \pi}\right) N}{4 \pi^{2}(\gamma-1) \gamma\left(m_{1} N\right)^{2}} ; \\
C_{(0)(1)}=\frac{j N A}{2} .
\end{gathered}
$$

Therefore, in the total current high frequency harmonics are partially eliminated:

$$
\begin{gathered}
C_{1}=j \frac{N A}{2} ; \\
C_{2 k-1}=0,2 k-1 \neq m_{1} N P+1,2 k-1 \neq m_{1} N P-1 ; \\
C_{m_{1} N P+1}=j \frac{A\left(1-e^{2 j \gamma m_{1} N \pi}\right)}{4 \pi^{2}(\gamma-1) \gamma m_{1}^{2} N} ; \\
C_{m_{1} N P-1}=-j \frac{A\left(1-e^{2 j \gamma m_{1} N \pi}\right)}{4 \pi^{2}(\gamma-1) \gamma m_{1}^{2} N} .
\end{gathered}
$$

Two cell current with phase shifting $\pi$ and $\gamma=0.3$ is reconstructed based on formulas (11), (14) and shown in Fig. 4.

When converter operates in DCM with relative zero pause duration $\gamma_{\mathrm{z}}$ and the cell current $i_{\text {cell }}$ shape is defined as follows:

$$
i_{\text {cell }}\left(x_{1}\right)=\left\{\begin{array}{l}
\frac{A \sin \left(x_{2}\right) x_{1}}{2 \pi \gamma}, 0 \leq x_{1}<2 \pi \gamma ; \\
\frac{A \sin \left(x_{2}\right)\left(2 \pi\left(1-\gamma_{z}\right)-x_{1}\right)}{2 \pi\left(1-\gamma-\gamma_{z}\right)}, \\
2 \pi \gamma \leq x_{1}<2 \pi\left(1-\gamma_{z}\right) ; \\
0,2 \pi\left(1-\gamma_{z}\right) \leq x_{1}<2 \pi .
\end{array}\right.
$$

the Double Fourier series expression for spectral component $C_{(m 1)(m 2)}$ is:

$$
\begin{gathered}
C_{\left(m_{1}\right)\left(m_{2}\right)}= \\
=\frac{A}{2 \pi^{2}} \int_{0}^{\pi} \sin \left(x_{2}\right)\left(\begin{array}{l}
\frac{1}{2 \pi \gamma} \int_{0}^{2 \pi \gamma} x_{1} e^{j\left(m_{1} x_{1}+m_{2} x_{2}\right)} d x_{1}- \\
-\frac{1}{2 \pi\left(1-\gamma-\gamma_{z}\right)} \int_{2 \pi \gamma}^{2 \pi\left(1-\gamma_{z}\right)} x_{1} e^{j\left(m_{1} x_{1}+m_{2} x_{2}\right)} d x_{1}+\frac{1}{\left(1-\gamma-\gamma_{z}\right)} \int_{2 \pi \gamma}^{2 \pi\left(1-\gamma_{z}\right)} e^{j\left(m_{1} x_{1}+m_{2} x_{2}\right)} d x_{1}
\end{array}\right) d x_{2}+ \\
+\frac{A}{2 \pi^{2}} \int_{\pi}^{2 \pi} \sin \left(x_{2}\right)\left(\begin{array}{l}
\frac{1}{2 \pi \gamma} \int_{0}^{2 \pi \gamma} x_{1} e^{j\left(m_{1} x_{1}+m_{2} x_{2}\right)} d x_{1}- \\
-\frac{1}{2 \pi\left(1-\gamma-\gamma_{z}\right)} \int_{2 \pi \gamma}^{2 \pi\left(1-\gamma_{z}\right)} x e^{j\left(m_{1} x_{1}+m_{2} x_{2}\right)} d x_{1}+\frac{1}{\left(1-\gamma-\gamma_{z}\right)} \int_{2 \pi \gamma}^{2 \pi\left(1-\gamma_{z}\right)} e^{j\left(m_{1} x_{1}+m_{2} x_{2}\right)} d x_{1}
\end{array}\right) d x_{2} .
\end{gathered}
$$

After series of transformation the spectral components in DCM defined as follow: 


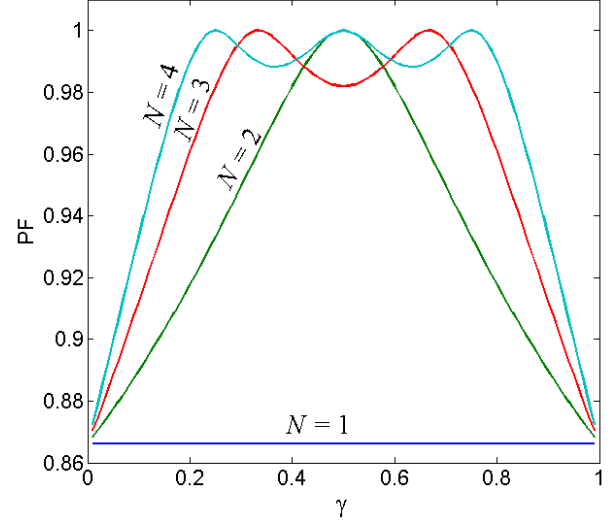

a)

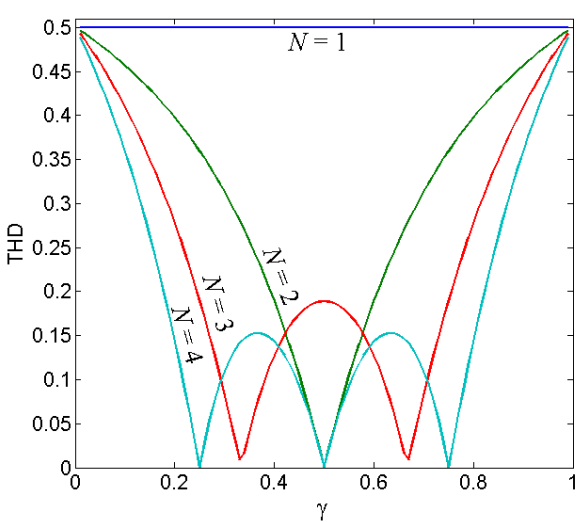

b)

Fig. 6. Functional behavior of PF (a) and THD (b) depend on duty cycle $\gamma$ and cell number $N$

$$
\begin{gathered}
C_{\left(m_{1}\right)(1)}=\frac{j A e^{-2 j \gamma_{z} m_{1} \pi}}{4 \pi^{2}\left(\gamma+\gamma_{z}-1\right) \gamma m_{1}{ }^{2}} \times\left(\gamma+e^{2 j\left(\gamma+\gamma_{z}\right) m_{1} \pi}\left(\gamma_{z}-1\right)-e^{-2 j \gamma_{z} m_{1} \pi}\left(\gamma_{z}+\gamma-1\right)\right) ; \\
C_{\left(m_{1}\right)(-1)}=-\frac{j A e^{-2 j \gamma_{z} m_{1} \pi}}{4 \pi^{2}\left(\gamma+\gamma_{z}-1\right) \gamma m_{1}{ }^{2}} \times\left(\gamma+e^{2 j\left(\gamma+\gamma_{z}\right) m_{1} \pi}\left(\gamma_{z}-1\right)-e^{-2 j \gamma_{z} m_{1} \pi}\left(\gamma_{z}+\gamma-1\right)\right) ; \\
C_{(0)(1)}=\frac{j A}{2}\left(1-\gamma_{z}\right) .
\end{gathered}
$$

According to formulas (4) and (10) nonzero harmonic are calculated as follows:

$$
\begin{gathered}
C_{1}=j \frac{A}{2}\left(1-\gamma_{z}\right) ; \\
C_{2 k-1}=0,2 k-1 \neq m_{1} P+1,2 k-1 \neq m_{1} P-1 ; \\
C_{m_{1} P+1}=\frac{j A e^{-2 j \gamma_{z} m_{1} \pi}}{4 \pi^{2}\left(\gamma+\gamma_{z}-1\right) \gamma m_{1}{ }^{2}} \times\left(\gamma+e^{2 j\left(\gamma+\gamma_{z}\right) m_{1} \pi}\left(\gamma_{z}-1\right)-e^{2 j \gamma_{z} m_{1} \pi}\left(\gamma_{z}+\gamma-1\right)\right) ; \\
C_{m_{1} P-1}=-\frac{j A e^{-2 j \gamma_{z} m_{1} \pi}}{4 \pi^{2}\left(\gamma+\gamma_{z}-1\right) \gamma m_{1}{ }^{2}} \times\left(\gamma+e^{2 j\left(\gamma+\gamma_{z}\right) m_{1} \pi}\left(\gamma_{z}-1\right)-e^{2 j \gamma_{z} m_{1} \pi}\left(\gamma_{z}+\gamma-1\right)\right) .
\end{gathered}
$$

The current shape of the two-cell converter for $\gamma=0.4$ and $\gamma_{z}=0.4$ is shown in Fig. 5.

After developing formulas of the cell current for $\mathrm{BCM}$ and DCM modes it is possible to calculate the PF and THD for different cell number.

\section{ESTIMATION CURRENT QUALITY PARAMETERS}

Let consider ideal input current PF and THD values for predefined number of cells $N$ in BCM. In comparison with one cell in $N$ modular converter high harmonics mainly eliminated except harmonics $C_{m P N+1}, C_{m P N-1}$. Input current RMS value $I_{\text {in } R M S(N)}$ may be calculated in closed analytical form:

$$
\begin{gathered}
I_{i n_{-} R M S(N)}= \\
=\sqrt{\frac{(A N)^{2}}{4}+2 \sum_{m_{1}=1}^{\infty}\left\lfloor\left.\frac{A N\left(1-e^{2 j \gamma m_{1} N \pi}\right)}{4 \pi^{2}(\gamma-1) \gamma\left(m_{1} N\right)^{2}}\right|^{2}\right.}= \\
=\frac{A N}{2} \sqrt{1+\frac{1}{3}\left(\frac{(\gamma N-\lfloor\gamma N\rfloor)((\gamma N-\lfloor\gamma N\rfloor)-1)}{(\gamma-1) \gamma N}\right)^{2}} .
\end{gathered}
$$

$\mathrm{PF}$ and THD of the modular converter calculated based on formula (17):

$$
\begin{gathered}
P F_{N}= \\
=\left(\sqrt{1+\frac{1}{3}\left(\frac{(\gamma N-\lfloor\gamma N\rfloor)((\gamma N-\lfloor\gamma N\rfloor)-1)}{(\gamma-1) \gamma N}\right)^{2}}\right)^{-1} ; \\
T H D_{N}=\frac{\left(\frac{(\gamma N-[\gamma N])(1-(\gamma N-[\gamma N]))}{(1-\gamma) \gamma N}\right)}{\sqrt{3+\left(\frac{(\gamma N-[\gamma N])((\gamma N-[\gamma N])-1)}{(\gamma-1) \gamma N}\right)^{2}}} .
\end{gathered}
$$

The same formulas for RMS current value $I_{i n ~ R M S(N) p}$ is obtained for current with relative zero current interval $\gamma_{z}$.

$$
I_{i n_{-} R M S(N) p}=\sqrt{\frac{(A N)^{2}}{4}\left(1-\gamma_{z}\right)^{2}+z},
$$

where 

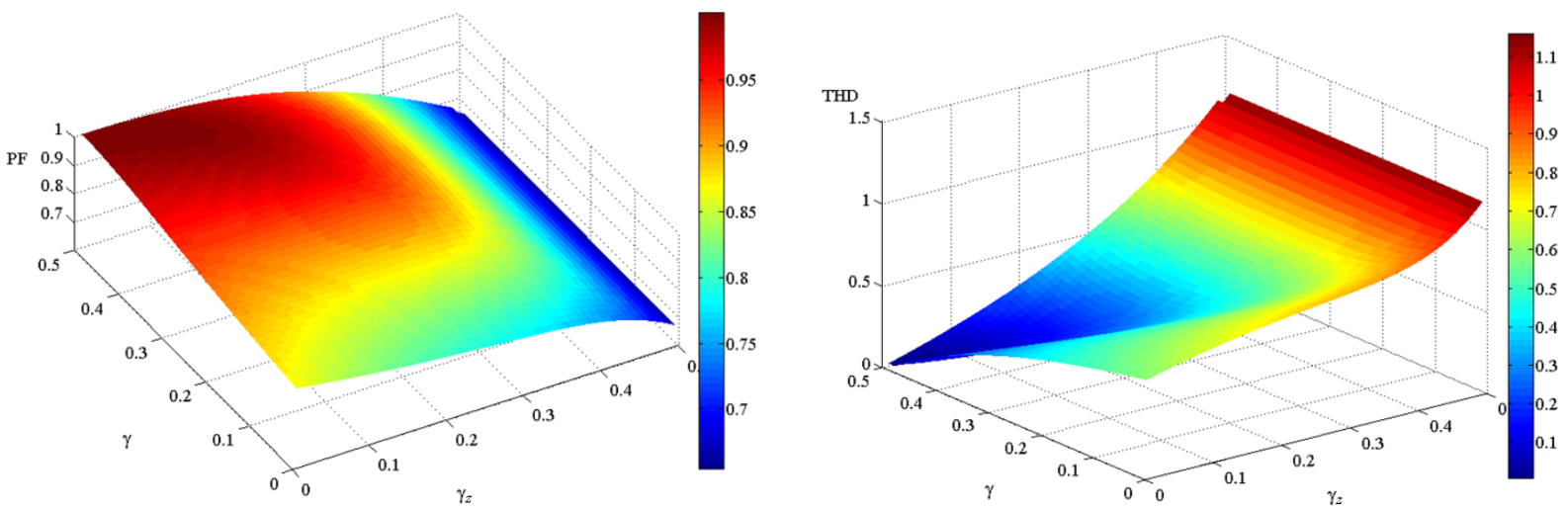

a)

a)
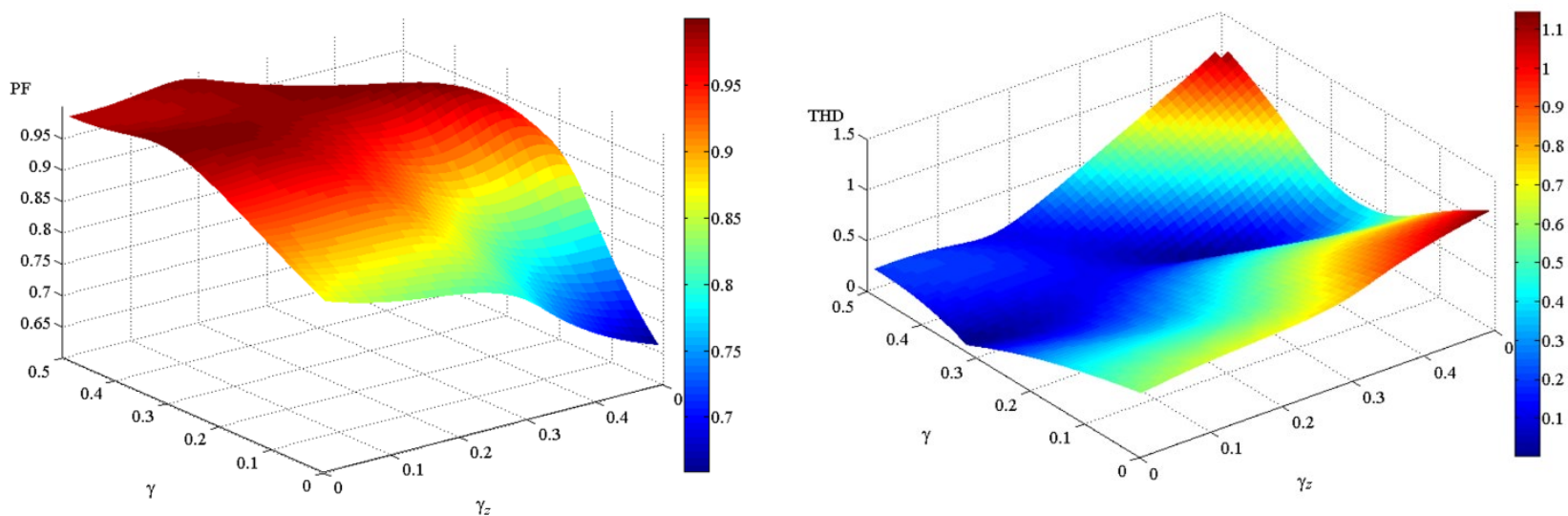

b)

b)

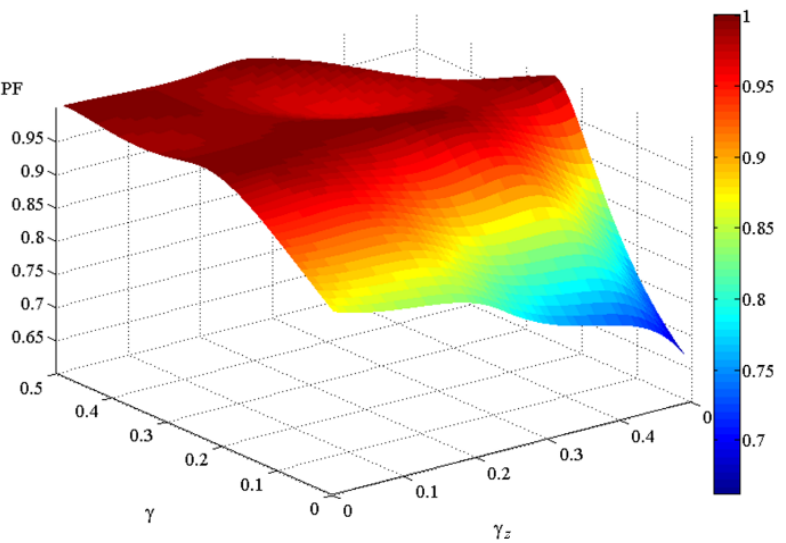

c)

Fig. 7. Functional behavior of PF: a) $N=2$, b) $N=3$, c) $N=4$

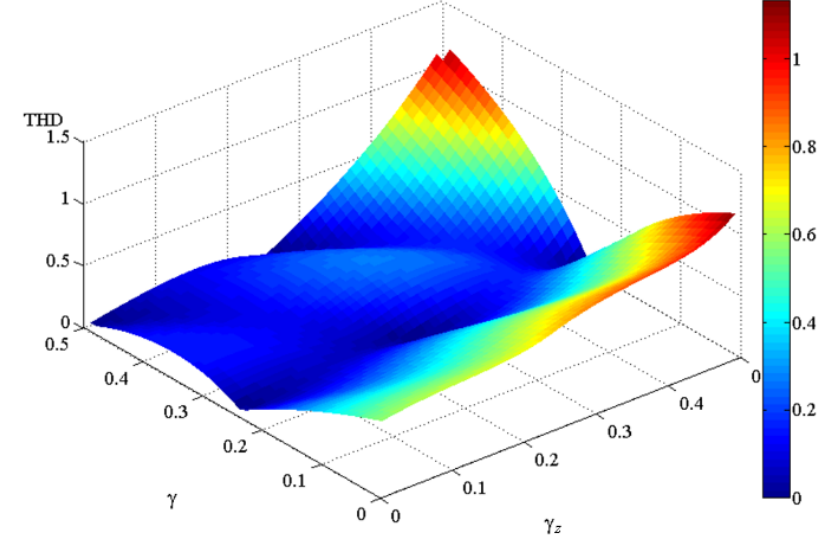

c)

Fig. 8. Functional behavior of THD: a) $N=2$, b) $N=3$, c) $N=4$ 


$$
\begin{gathered}
z=2\left(\frac{1}{4 \pi^{2}\left(\gamma+\gamma_{z}-1\right) \gamma N}\right)^{2} \times \\
\frac{\pi^{4}}{90 N^{2}}\left(\left(\gamma^{2}+\left(\gamma_{z}-1\right)^{2}+\left(\gamma_{z}+\gamma-1\right)^{2}\right)+\right. \\
+2 \gamma\left(\gamma_{z}-1\right)\left(1-30\left(\left(\gamma_{z}+\gamma\right) N-\left\lfloor\left(\gamma_{z}+\gamma\right) N\right\rfloor\right)^{2}+\right. \\
+60\left(\left(\gamma_{z}+\gamma\right) N-\left\lfloor\left(\gamma_{z}+\gamma\right) N\right\rfloor\right)^{3}- \\
\left.-30\left(\left(\gamma_{z}+\gamma\right) N-\left\lfloor\left(\gamma_{z}+\gamma\right) N\right\rfloor\right)^{4}\right)- \\
-2\left(\gamma_{z}-1\right)\left(\gamma_{z}+\gamma-1\right)\left(1-30(\gamma N-\lfloor\gamma N\rfloor)^{2}+\right. \\
\left.+60(\gamma N-\lfloor\gamma N\rfloor)^{3}-30(\gamma N-\lfloor\gamma N\rfloor)^{4}\right)- \\
-2 \gamma\left(\gamma_{z}+\gamma-1\right)\left(1-30\left(\gamma_{z} N-\left\lfloor\gamma_{z} N\right\rfloor\right)^{2}+\right. \\
\left.+60\left(\gamma_{z} N-\left\lfloor\gamma_{z} N\right\rfloor\right)^{3}-30\left(\gamma_{z} N-\left\lfloor 2 \gamma_{z} N\right\rfloor\right)^{4}\right) .
\end{gathered}
$$

PF and THD for defined RMS current value (21) defined as follow:

$$
\begin{gathered}
P F_{N p}==\frac{0.5 A \cdot N\left(1-\gamma_{z}\right)}{\sqrt{0.5 A \cdot N\left(1-\gamma_{z}\right)+z}} ; \\
T H D_{N p}=\frac{z}{0.5 A \cdot N\left(1-\gamma_{z}\right)} .
\end{gathered}
$$

Functional behavior of PF and THD depend on duty cycle $\gamma$ and cell number $N$ for BCM is shown in Figure 6 a) and 6 b) respectively.

As we can see increasing of cells $N$ significantly improves PF and THD and extends range of duty cycle $\gamma$ where they have good enough value, $\gamma \in[1 / N ; 1-1 / N]$.

PF and THD behavior for DCM is more complex because of additional parameter of relative zero current pause $\gamma_{z}$. The functional dependences of PF are shown in Fig. 7 a), b), c) for $N=2, N=3, N=4$ respectively.

The same functional dependence may be obtained for any $N$ with formulas (24) and (25), therefore developed formulas may be used for estimation number of cells $N$ for predefined PF or THD.

\section{CONCLUSIONS}

In the paper the formulas for THD and PF parameters based on Double Fourier series for modular SEPIC converter valid for different cell number $N$ are obtained. The obtained functions allow to simplify to determine cell number to defined THD and PF values for duty cycle $\gamma$ range and relative zero current interval duration $\gamma_{z}$.

\section{REFERENCES}

[1] Murat Yilmaz, Philip T. Krein., «Review of Battery Charger Topologies, Charging Power Levels, and Infrastructure for Plug-In Electric and Hybrid Vehicles,» in IEEE Transactions on Power

\footnotetext{
Надійшла до редакції 23 листопада 2019 р.
}

Electronics, Vol. 28, № 5, 2013, Pp. 2151-2169, DOI:10.1109/TPEL.2012.2212917.

[2] Shesh Narayan Vaishnav; H. Krishnaswami, «Single-stage Isolated Bi-directional Converter Topology using High Frequency AC link for Charging and V2G Applications of PHEV,» in 2011 IEEE Vehicle Power and Propulsion Conference, 2011. - DOI: 10.1109/VPPC.2011.6043138

[3] F. Jauch; J. Biela, «Single-Phase Single-Stage Bidirectional Isolated ZVS AC-DC Converter with PFC,» in 15th International Power Electronics and Motion Control Conference, EPE-PEMC 2012 ECCE Europe, Novi Sad, Serbia, DOI: $10.1109 / E P E P E M C .2012 .6397479$.

[4] U. R. Prasanna; A. K. Singh; K. Rajashekara, «Novel Bidirectional Single-phase Single-Stage Isolated AC-DC Converter With PFC for Charging of Electric Vehicles,» in IEEE Transactions on Transportation Electrification, 2017, 3(3), pp. 536-544, DOI: $10.1109 /$ TTE.2017.2691327

[5] F. Yang; C. Li; Y. Cao; K. Yao, «Two-phase Interleaved Boost PFC Converter with Coupled Inductor under Single-phase Operation,» in IEEE Transactions on Power Electronics, 2019, 1-1, DOI:10.1109/TPEL.2019.2914532.

[6] Y. Liu; Y. Sun; M. Su. A, «Control Method for Bridgeless Cuk/Sepic PFC Rectifier to Achieve Power Decoupling,» in IEEE Transactions on Industrial Electronics, 2017, 64(9), pp. 7272-7276, DOI: 10.1109/TIE.2017.2688979.

[7] P. J. S. Costa; C. H. Illa Font; T. B. Lazzarin, «Single-Phase Hybrid Switched-Capacitor Voltage-Doubler SEPIC PFC Rectifiers,» in IEEE Transactions on Power Electronics, 2018, 33(6), pp. 5118-5130, DOI: 10.1109/TPEL.2017.2737534.

[8] D. Wu; R. Ayyanar; M. Sondharangalla; T. Meyers, «High Performance Active-Clamped Isolated SEPIC PFC Converter with $\mathrm{SiC}$ Devices and Lossless Diode Clamp,» in IEEE Journal of Emerging and Selected Topics in Power Electronics, 2019, 11, DOI: 10.1109/JESTPE.2019.2944593

[9] I. Galkin; A. Podgornovs; A. Blinov; K. Vitols; M. Vorobyov; R. Kosenko, «Considerations regarding the concept of cost-effective power-assist wheelchair subsystems,» in Electr. Control Commun. Eng., 2018, 14, pp. 71-80, DOI: 10.3390/en12081526.

[10] I. Galkin; A. Blinov; I. Verbytskyi; D. Zinchenko, «Modular Self-Balancing Battery Charger Concept for Cost-Effective Power-Assist Wheelchairs,» in Energies 2019, 12, 1526, DOI: 10.3390/en12081526.

[11] Vasca, F.; Iannelli, L, «Dynamics and Control of Switched Electronic Systems: Advanced Perspectives for Modeling, Simulation and Control of Power Converters (Advances in Industrial Control) ,» in Springer-Verlag, London, 2012. - 493 p, DOI: $10.1007 / 978-1-4471-2885-4$.

[12] Ievgen Verbytskyi, Oleksandr Bondarenko, Oleksandr Kaloshyn, «Multicell-type charger for supercapacitors with power factor correction,» in Young Engineers Forum (YEF$E C E)$, Costa da Caparica, Portugal, 2018, pp. 91-96, DOI: 10.1109/YEF-ECE.2018.8368945.

[13] Holmes, D. Grahame; Lipo, Thomas A, «Pulse width modulation for power converters. Theory and practice,» in IEEE Press Series on Power Engineering, 2003. - $724 \mathrm{p}$.

[14] Verbytyskyi, I.V, «Ispolzovanie dvoynogo ryada Furie dlya rascheta spectra modulirovannyh signalov [ Using of Double Fourier series for modulated signals spectrum calculation],» in Technichna elekrtrodynamika [ Technical Electrodynamics] - 2014, № 4, p. 96-98. 
УдК 621.314

\title{
Аналіз параметрів якості вхідного струму модульного АC-DC зарядного пристрою SEPIC на основі ряду Фур'є двох змінних
}

\author{
Вербицький С. В., к.т.н. доц., ORCID 0000-0001-7275-5152 \\ Кафедра електронних пристроїв та систем eds.kpi.ua \\ Національний технічний університет України \\ «Київський політехнічний інститут ім. Ігоря Сікорського» kpi.ua \\ Київ, Україна
}

Анотація-У статті розглянуто можливі топологї̈ зарядних пристроїв змінного струму з активною корекцією коефіцієнта потужності. Виділено одноланкові і дволанкові топологї̈ зарядних пристроїв та обтрунтовано доцільність використання першої групи перетворювачів через менші габарити та простішу структуру. Серед одноланкових перетворювачів наголочено на перевагах модульних перетворювачів з чергуванням фаз на основі топології SEPIC, щңо мають мінімальні динамічні втрати, простий алгоритм та схемну реалізацію корекції коефіцієнта потужності у граничному режимі протікання струму (ГРП) та невеликі габарити. Функціонування модульних перетворювачів проаналізовано на прикладі двокоміркового перетворювача та показано принцип покращення форми вхідного струму за умови зсуву імпульсів керування кожної комірки. Як результат, встановлено функціональну залежність параметрів якості електроенерхї̈ (коефіцієнт потужнності РF і коефіцієнт нелінійних спотворень ТНD) від коефіцієнта заповнення імпульсів кожної комірки перетворювача. Оскільки у реальних перетворювачах складно дотримуватись ГРП, а в неперервному режимі форма вхідного струму спотворюється, такі перетворювачі працюють у переривчастому режимі протікання (ПРП) струму. На основі аналізу схем заміщення для трьох інтервалів роботи перетворювача SEPIC-інтервал наростання вхідного струму, інтервал спадання вхідного струму та інтервалу нульової паузи - створено його математичну модель. Показано, що збільшення тривалості нульової паузи протікання струму суттєво погіршує значення коефіцієнта потужсності PF і коефіцієнта нелінійних спотворень ТНD. Внаслідок цього параметри РF і THD с функціями коефіцієнта заповнення імпульсів і тривалості паузи і мають складну залежність. Тому для оцінки кількості комірок перетворювача, щи забезпечують необхідні значення РF і THD доцільно вивести ці залежності в аналітичній формі, щз здійснено на основі використання ряду Фур'є двох змінних. Отримані залежності спрощують вибір кількості комірок перетворювача для заданого діапазону коефіцієнта заповнення імпульсів і значення відносної нульової паузи. На основі отриманих формул побудовано залежність РF $і$ THD для двох, трьох і чотирьох комірок.

Ключові слова - модульний перевторювач; SEPIC перевтворювач; зарядний пристрій; корекція коефіцієнта потужсності; ряд Фур'є двох змінних 


\title{
Анализ параметров качества входного тока модульного AC-DC зарядного устройства SEPIC на основе ряда Фурье двух переменных
}

\author{
Вербицкий Е. В., к.т.н. доц., ORCID 0000-0001-7275-5152 \\ Кафедра электронных устройств и систем eds.kpi.ua \\ Национальный технический университет Украины \\ "Киевский политехнический институт имени Игоря Сикорского" kpi.ua \\ Киев, Украина
}

Аннотация-В статье рассмотрены возможные топологии зарядных устройств переменного тока с активной коррекцией коэффициента мощности. Выделено однозвенных и двухзвенных топологии зарядных устройств и обоснована целесообразность использования первой группы преобразователей через меньшие габариты и простую структуру. Среди однозвенного преобразователей отмечена преимуществах модульных преобразователей с чередованием фаз на основе топологии SEPIC, имеющих минимальные динамические потери, простой алгоритм и схемную реализацию коррекции коэффициента мощности в предельном режиме протекания тока (ГРП) и небольшие габариты. Функционирование модульных преобразователей проанализированы на примере двухячеестого преобразователя и показано принцип улучшения формы входного тока при сдвига импульсов управления каждой ячейки. Как результат, установлено функциональную зависимость параметров качества электроэнергии (коэффициент мощности PF и коэффициент нелинейных искажений THD) от коэффициента заполнения импульсов каждой ячейки преобразователя. Поскольку в реальных преобразователях сложно придерживаться ГРП, а в непрерывном режиме форма входного тока искажается, такие преобразователи работают в прерывистом режиме протекания (ПРП) тока. На основе анализа схем замещения для трех интервалов работы преобразователя SEPIC - интервал нарастания входного тока, интервал падения входного тока и интервала нулевой паузы - создано его математическую модель. Показано, что увеличение продолжительности нулевой паузы протекания тока существенно ухудшает значение коэффициента мощности РF и коэффициента нелинейных искажений THD. В результате параметры РF и THD являются функциями коэффициента заполнения импульсов и длительности паузы и имеют сложную зависимость. Поэтому для оценки количества ячеек преобразователя, обеспечивающих требуемые значения PF и THD целесообразно вывести эти зависимости в аналитической форме, осуществлено на основе использования ряда Фурье двух переменных. Полученные зависимости упрощают выбор количества ячеек преобразователя для заданного диапазона коэффициента заполнения импульсов и значение относительной нулевой паузы. На основе полученных формул построено зависимость PF и THD для двух, трех и четырех ячеек.

Ключевые слова - модульный преобразователь; SEPIC преобразователь; зарядное устройство; коррекция коэффициента мощности; ряд Фурье двух переменных 